\title{
Indications that some nutritional elements can improve gladiolus corm and cormel qualities in Mexico
}

\author{
Enrique González-Pérez ${ }^{*}$, Óscar Javier Ayala-Garay ${ }^{2}$, and María de Jesús Yáñez-Morales ${ }^{3}$
}

\begin{abstract}
In regions of the State of Puebla (Mexico), gladiolus (Gladiolus grandiflorus Andrews) production has had asexual propagation problems, which have caused losses for producers, who mostly produce their own vegetative seeds. The aim of this study was to evaluate some physical qualities and health characteristics of corms and cormels generated at four fertilization rates (FD, kg ha-1): 65N-14.9P-171K-16.6Mg-31.2Ca-0.0B-0.0S (FD1); 40.5N-24P-171K-23Mg-37.2Ca0.2B-8.5S (FD2); 81N-24P-171K-23Mg-37.2Ca-0.2B-0.0S (FD3); and 81N-24P-171K-23Mg-37.2Ca-0.0B-0.0S (FD$\mathrm{R}$; traditional regional rate). Two hundred and forty corms, along with their cormels, of two varieties ('Borrega Roja' and 'Espuma') produced at four FDs were harvested. The following physical qualities of corms were assessed; corm fresh weight (CFW), number of cormels generated (NcMC), and total fresh weight (TFW); evaluated physical qualities of cormels were size $(\mathrm{mm})$ and total weight. Cormel health was analyzed in 160 randomly disinfested pieces that were plated in agar medium with or without splitting. The percentage of identified fungus incidence was recorded. Data were analyzed by a non-parametric one-way ANOVA. No significant differences were shown for CFW. The best treatments were mainly FD2 followed by FD1. In relation to FD-R, FD2 in both varieties increased NcMC by $31 \%$ to $69 \%$, TFW by $27 \%$ to $46 \%$, 6-8 size by $24 \%$ to $27 \%$, and the development of Fusarium oxysporum colonies was reduced by $100 \%$ in cormel internal tissue.
\end{abstract}

Key words: Gladiolus grandiflorus, macronutrients, micronutrients, ornamental, vegetative seed.

\section{INTRODUCTION}

Gladiolus (Gladiolus grandiflorus Andrews) is an appreciated ornamental plant worldwide (Halder et al., 2007), whose corms are used for asexual propagation. A plant is originated from a corm and from the underground stem a new corm is formed, which produces cormels at its base. Both these structures are used as vegetative seeds (Cantor and Tolety, 2011). In Mexico, there are 3600 ha of gladiolus plantations and the State of Puebla is the leading producer with $38 \%$ of national production (SIAP, 2012). Some of the main gladiolus varieties grown in the San Martin Texmelucan (SMT) region in the State of Puebla are 'Borrega Blanca', 'Borrega Roja', 'Espuma', and 'Grand Prix'. Most farmers in this area produce their own seeds; therefore, $10 \%$ of the total surface is devoted to cormel and corm production. One of the main problems in this region is that farmers use their own vegetative

\footnotetext{
${ }^{1}$ Instituto Nacional de Investigaciones Forestales, Agrícolas y Pecuarias, Campo Experimental Bajío, km 6,5 Carretera CelayaSan Miguel de Allende, Celaya, Guanajuato. 38110. Guanajuato, México. "Corresponding author (gonzalez.enrique@inifap.gob.mx; yanezmj@colpos.mx).

${ }^{2}$ Colegio de Postgraduados, Campus Montecillo, km 36,5 Carr. México-Texcoco. C.P. 56230 Montecillo, Texcoco, México.

Received: 11 June 2013.

Accepted: 9 January 2014.

doi:10.4067/S0718-58392014000100011
}

seeds; these are stored under uncontrolled conditions (humidity and temperature) that reduce their quality with consequent health loss during the growth period (Cohat, 1993). During crop development, corms can also get various diseases from soilborne fungi or from the same propagules, which leads to estimated losses of $40 \%$ to $70 \%$ by plant wilt. Then the same asexual seed contributes to the spread of diseases in the field (González-Pérez et al., 2009).

Several ornamental crops are infected mainly by species of Fusarium and their control depends on managing crop factors such as cultural practices, cultivar resistance, nutrition, and environmental conditions. Efforts to control potential $F$. oxysporum inoculums are the following: treating bulbs with hot water, either alone or in combination with a fungicide treatment (Gullino et al., 2012); bulb, corm, and seed irradiation with shortwave ultraviolet light at low exposition time is also an alternative to avoid fungicides (Elmer and McGovern, 2004) as well as adjusting soil $\mathrm{pH}$ between 6.5-7.0 (Gullino et al., 2012). Moreover, some nutrient elements are recommended to control Fusarium wilt, such as low $\mathrm{N}$ rates (Engelhard, 1989); this element in excess promotes the development of Fusarium that affects the physical health and quality of the corms (González-Pérez, 2006). Other nutrients to decrease corm rot are K (Gullino et al., 2012) and S (Chandel and Deepika, 2010). In other crops, $\mathrm{S}\left(100 \mathrm{~N}-20 \mathrm{~S}-46 \mathrm{P}_{2} \mathrm{O}_{5} \mathrm{~kg} \mathrm{~h}^{-1}\right)$ in wheat production was 
effective to control root rot by Fusarium spp. (Melgar et al., 2001), whereas in carnation (Dianthus caryophyllus L.), B and Ca maintain proper soil $\mathrm{pH}$ (6.5-7.5) and limit the development of Fusarium spp. (Engelhard, 1989).

On the other hand, using organic amendments that contain large amounts of fertilizer enhance the disease (Gullino et al., 2012). This is the case in carnation where $\mathrm{N}$ at more than $100 \mathrm{~kg} \mathrm{ha}^{-1}$ induces root rot (Engelhard, 1989). In the region of the present study, no available technical information to manage corm rot by Fusarium has been generated and farmers apply crop rotation to reduce the disease and only plant the gladiolus crop in the same field every $5 \mathrm{yr}$.

Fertilization practices are mainly applied to improve the overgrown physical quality of the gladiolus crop in the hope of obtaining better physical vegetative seed; this depends on climatic conditions, irrigation method, and soil type (Shaukat et al., 2012). A proper nutrient balance of N, P (200 kg ha-1; Lehry et al., 2011), K, and micronutrients such as $\mathrm{B}$ are necessary to increase the number of cormels per corm (Khan and Ahmad, 2004; Halder et al., 2007). More specifically, the combination of $\mathrm{N}\left(50 \mathrm{~kg} \mathrm{ha}^{-1}\right)$ and $\mathrm{K}\left(77.5 \mathrm{~kg} \mathrm{ha}^{-1}\right)$ promotes the reproduction of cormels (Butt, 2005). Furthermore, N, P, and $\mathrm{K}$ in a proportional relationship $\left(5: 5: 5 \mathrm{~g} \mathrm{pot}^{-1}\right)$ increase the diameter and weight of corms (Khan and Ahmad, 2004), whereas an excess of $\mathrm{N}$ promotes vegetative growth at the expense of size and corm sanitary quality. This happens when the N:P proportion is different to the ratio 3N:1P (Vidalie, 2001). By itself, $\mathrm{P}$ at rates higher than $40 \mathrm{~kg} \mathrm{ha}^{-1}$ induces larger corms and increases the number and size of cormels and in a deficient rate affects the growth of gladiolus corms (Hossian et al., 2011; Shaukat et al., 2012). For K, rates greater than $100 \mathrm{~kg}$ $\mathrm{ha}^{-1}$ increase cormel production due to the effect of $\mathrm{K}$ on the translocation of newly synthesized photosynthates and their mobilization of stored materials in the mother corm (Zubair, 2011). Other elements such as $\mathrm{Ca}$ and $\mathrm{Mg}$ are related to flower vase life (Bai et al., 2009). In gladiolus, adding $\mathrm{B}$ at $1.0 \mathrm{~kg} \mathrm{ha}^{-1}$ increases the number and size of corms (Halder et al., 2007) and in tulip (Tulipa gesneriana L.) B deficiency induces smaller bulb size (Bobadilla and Chimenti, 2013). In SMT, Puebla, some soils are deficient in macro- and micronutrients so that farmers traditionally apply a fertilization rate of $81 \mathrm{~N}-24 \mathrm{P}-171 \mathrm{~K}-37.2 \mathrm{Ca}-23 \mathrm{Mg}-0 \mathrm{~B}-0 \mathrm{~S} \mathrm{~kg} \mathrm{ha} \mathrm{k}^{-1}$ to enhance gladiolus flower crop production although Fusarium wilt disease and vegetative seed quality are unresolved (González-Pérez; personal communication). Based on the above, the aim of this study was to evaluate some physical qualities and health characteristics in gladiolus corm and cormels generated at different fertilization rates, assuming that adding some nutritional elements and adjusted rates produce better gladiolus vegetative seeds than the ones currently used by the farmers in the study area.

\section{MATERIALS AND METHODS}

The study was carried out in San Martin Texmelucan (SMT), Puebla in the Tlacotepec de José Manzo community belonging to $\mathrm{El}$ Verde municipality (19²'18" N; 98²6'54" W; $2425 \mathrm{~m}$ a.s.1.) with Cw type climate (García, 2004) in clay loam and slightly acid soil (Table 1).

\section{Plant material and treatments}

From a previous field experiment carried out in July 2009 (González-Pérez et al., 2011), 240 corms and cormels of 'Borrega Roja' and 'Espuma' were harvested with field fertilization rate (FD) experiments and then evaluated. Treatments were four FDs, including the regional rate (FD-R; Larson, 1992), and three other new estimated combinations, FDs 1 to 3 . The experiment was conducted in a factorial randomized complete block design with four replicates (Table 2). Fertilizer sources were agricultural lime, ammonium nitrate, borax, di-ammonium phosphate, magnesium sulfate, potassium chloride, and potassium nitrate $\left(\mathrm{kg} \mathrm{ha}^{-1}\right)$.

From preliminary experiments, the new FDs 1 to 3 were estimated and the traditional regional FD-R used by farmers was the reference point. A total of 81 combinations (nutrient elements and rates) were calculated and 12 were selected by a 'San Cristobal' matrix (Martínez and Martínez, 1998) and evaluated in vitro to know which ones had some kind of negative influence on the physiology or nutrition of Fusarium. In agar medium emended with a proportional rate of 12 selected combinations, four

Table 1. Content characteristics of a clay loam and slightly acid soil analysis in the community of Tlacotepec de José Manzo, El Verde, Puebla.

\begin{tabular}{|c|c|c|}
\hline Soil characteristic $^{1}$ & Value & Classification \\
\hline $\mathrm{pH}$ & 5.8 & Low \\
\hline Bulk density, $\mathrm{g} \mathrm{cm}^{-3}$ & 1.43 & High \\
\hline Organic matter, $\%$ & 2.73 & Medium \\
\hline Electrical conductivity, $\mathrm{dS} \mathrm{m}^{-1}$ & 0.116 & Low \\
\hline $\mathrm{N}, \mathrm{kg} \mathrm{ha}^{-1}$ & 113.7 & Medium \\
\hline $\mathrm{P}, \mathrm{mg} \mathrm{L}^{-1}$ & 43 & Very low \\
\hline $\mathrm{K}, \mathrm{mg} \mathrm{L}^{-1}$ & 15 & Low \\
\hline $\mathrm{Ca}^{\Delta}, \mathrm{mg} \mathrm{L}^{-1}$ & 58 & Medium \\
\hline $\mathrm{Mg}^{\Delta}, \mathrm{mg} \mathrm{L}^{-1}$ & 62.8 & Medium \\
\hline $\mathrm{S}^{\Delta}, \mathrm{mg} \mathrm{L}^{-1}$ & 53 & Medium \\
\hline $\mathrm{B}, \mathrm{mg} \mathrm{L}^{-1}$ & 0.3 & Very low \\
\hline
\end{tabular}

${ }^{1}$ Analysis performed by A\&L Agricultural Laboratories (Pompano Beach, Florida, USA) during 2010.

${ }^{\Delta}$ Total amount.

Table 2. Composition of four fertilizer rates used in the production of corms and cormels of two gladiolus varieties (Tlacotepec de José Manzo, El Verde, Puebla) during the 2009 spring-summer cycle.

\begin{tabular}{|c|c|c|c|c|c|c|c|c|}
\hline Rates & $\mathrm{N}$ & $\mathrm{P}$ & $\mathrm{K}$ & $\mathrm{Ca}$ & $\mathrm{Mg}$ & B & $\mathrm{S}$ & References \\
\hline & & & & $\mathrm{kg} \mathrm{ha}^{-1}$ & & & & \\
\hline FD1 & 65 & 14.9 & 171 & 31.2 & 16.6 & 0 & 0 & González-Pérez, 2006 \\
\hline FD2 & 40.5 & 24 & 171 & 37.2 & 23 & 0.2 & 8.5 & González-Pérez, 2006 \\
\hline FD3 & 81 & 24 & 171 & 37.2 & 23 & 0.2 & 0 & González-Pérez, 2006 \\
\hline FD-R & 81 & 24 & 171 & 37.2 & 23 & 0 & 0 & Larson, 1992 \\
\hline
\end{tabular}

FD-R: Traditional fertilization rate (FD) used in the region (R) under study. 
F. oxysporum f. sp. gladioli isolates were plated in 12 treatments with three replicates of each one; the ones that showed a retarding growth rate of the fungus were chosen to prepare FD1 (rates estimated from FD-R less nutrient contribution from irrigation water; González-Pérez, 2006), FD2, and FD3 combinations (González-Pérez, 2006).

In addition to the desired cormel health characteristics, a study was designed to know if these three new FD combinations also had beneficial effects on physical qualities of the vegetative seed produced.

\section{Corm and cormel analysis}

During harvest, 30 mother corms (MC) along with their cormels were randomly selected for each treatment (four FDs) and variety ('Borrega Roja' and 'Espuma'). In the $\mathrm{MC}$, evaluated variables were: corm fresh weight (CFW, $\mathrm{g}$ ), number of cormels produced per corm ( $\mathrm{NcMC})$, and total fresh weight of cormels (TFW, g).

In cormels separated from the MC, size (mm), TFW, and health were assessed. In order to determine cormel size, these were sieved through $50 \times 80 \mathrm{~cm}$ sieves of different mesh diameters $(\mathrm{mm})$. Cormels were classified according to the mesh size used and their TFW was recorded by size.

\section{Cormel health}

This parameter was evaluated in 160 random cormels (20 per treatment and variety). Each of the cormel tunics was removed and rinsed in running water for 20 min (soil removal) and dried over sterile towels inside a laminar flow chamber. Cormels were disinfested with a $1.5 \%$ sodium hypochlorite solution for $3 \mathrm{~min}$ and dried as mentioned above. Then cormels were rinsed three times with sterile distilled water and re-dried inside the chamber. Eighty cormels were planted directly in Petri dishes with PDA (potato-dextrose-agar; Bioxon, Mexico) and the remainder were split longitudinally and plated in the same medium with the inner side tissue in contact with the medium. All the Petri dishes were incubated for $12 \mathrm{~d}$ at $21{ }^{\circ} \mathrm{C}$ with a continuous $40 \mathrm{~W}$ white light. As fungal colonies developed, the incidence rate per cormel was recorded. The fungi species were identified with the same methodology described in González-Pérez (2006) and González-Pérez et al. (2009). Literature techniques and descriptions were also used for the main Fusarium species that cause corm rot (Booth, 1971; Nelson et al., 1983; Leslie and Summerell, 2006).

\section{Statistical analysis}

Non-parametric one-way ANOVA and rank mean comparisons by the Kruskal-Wallis test ( $\mathrm{p} \leq 0.05$ ) (Kruskal and Wallis, 1952) were done to obtain data with the Statistical Analysis System software (SAS Institute, 2009).

\section{RESULTS AND DISCUSSION}

The field factorial design was unable to comparatively analyze the effect of interaction between varieties and FDs because seven nutrients included in formulating the four FDs (Table 2) were not analyzed individually in different treatments. The exceptions were FD3 and FD-R (traditional regional rate), which were different only for B. However, FD-R had the worst values in all the parameters evaluated followed for FD3 (with B); B in soil of the present study had very low rates (Table 1), thus indicating that possibly the $\mathrm{B}$ rate used was inadequate for gladiolus plants. Also, possibly in FD-R, the high $\mathrm{N}$ rate composition plus the medium amount of $\mathrm{N}$ in the soil (Table 1) benefited vegetative growth at the expense of smaller size and lower cormel sanitary quality (Vidalie, 2001).

\section{Some corm physical qualities}

There were significant differences only among NcMC and TFW parameters and some of the FD treatments ( $p$ $\leq 0.05$ ) (Table 3). For CFW, any one of the three FDs and FD-R in each variety showed significant effects. The highest NcMC was with FD2 in both varieties and equal to FD1 only in 'Borrega Roja'. For TFW, FD1 was the best in 'Borrega Roja', while it was the best for FD2 in 'Espuma'. A direct proportion between NcMC and TFW was shown by FD1 in the first variety and the same with FD2 in the last variety. For the three parameters, FD3 was significantly equal to the traditional regional FD-R and both showed the lowest values (Table 3).

The fact that for TFW, FD1 was better for one variety and FD2 for another variety was related to the expected variation in genetic constitution of each variety and therefore, possibly their nutrient and rate requirements were different for NcMC with FD1.

\section{Cormel physical qualities and health}

There were significant differences $(\mathrm{p} \leq 0.05)$. The generated cormels were classified into five sizes and

Table 3. Mother corm and cormel physical qualities of two gladiolus varieties at four fertilization rates (FD; $\mathrm{kg} \mathrm{ha}^{-1}$ ) (Tlacotepec de José Manzo, EI Verde, Puebla) during the 2009 spring-summer cycle.

\begin{tabular}{lccc}
\hline FD & $\begin{array}{c}\text { Mother corm } \\
\text { weight }\end{array}$ & $\begin{array}{c}\text { Number of cormels } \\
\text { per mother corm }\end{array}$ & $\begin{array}{c}\text { Cormel total } \\
\text { fresh weight }\end{array}$ \\
\hline & $\mathrm{g}$ & 'Borrega Roja' & $\mathrm{g}$ \\
FD1 & $6.1 \mathrm{~b}$ & $53.0 \mathrm{a}$ & $173.1 \mathrm{a}$ \\
FD2 & $5.8 \mathrm{~b}$ & $53.5 \mathrm{a}$ & $166.2 \mathrm{bc}$ \\
FD3 & $5.3 \mathrm{~b}$ & $44.8 \mathrm{ab}$ & $80.5 \mathrm{~d}$ \\
FD-R & $5.2 \mathrm{~b}$ & $36.8 \mathrm{~b}$ & $77.3 \mathrm{~cd}$ \\
& & 'Espuma' & \\
FD1 & $10.8 \mathrm{a}$ & $18.5 \mathrm{c}$ & $148.1 \mathrm{bc}$ \\
FD2 & $11.2 \mathrm{a}$ & $38.5 \mathrm{~b}$ & $172.3 \mathrm{ab}$ \\
FD3 & $9.9 \mathrm{a}$ & $16.0 \mathrm{c}$ & $84.6 \mathrm{~cd}$ \\
FD-R & $11.7 \mathrm{a}$ & $12.0 \mathrm{c}$ & $47.2 \mathrm{~d}$ \\
\hline
\end{tabular}

FD1: $65 \mathrm{~N}-14.9 \mathrm{P}-171 \mathrm{~K}-16.6 \mathrm{Mg}-31.2 \mathrm{Ca}-0.0 \mathrm{~B}-0.0 \mathrm{~S}$; FD2: $40.5 \mathrm{~N}-24 \mathrm{P}-$ $171 \mathrm{~K}-23 \mathrm{Mg}-37.2 \mathrm{Ca}-0.2 \mathrm{~B}-8.5 \mathrm{~S} ; \quad$ FD3: $81 \mathrm{~N}-24 \mathrm{P}-171 \mathrm{~K}-23 \mathrm{Mg}-37.2 \mathrm{Ca}-$ $0.2 \mathrm{~B}-0.0 \mathrm{~S}$; FD-R (regional traditional fertilization rate): $81 \mathrm{~N}-24 \mathrm{P}-171 \mathrm{~K}-$ $23 \mathrm{Mg}-37.2 \mathrm{Ca}-0.0 \mathrm{~B}-0.0 \mathrm{~S}$.

The same letter within a column indicates no significant differences according to the Kruskal-Wallis rank mean test ( $\mathrm{p} \leq 0.05)$. 
weight (TFW) varied depending on the size (Table 4). In both varieties, 6-8 size showed the highest TFW mainly with FD2 followed by FD1 only in 'Borrega Roja'. Regarding the four FDs, the 10-12 size (considered ideal for propagation) had the lowest TFW and the 2-4 size recorded the worst TFW.

External tissue. Significant differences were observed. The lowest incidence of Fusarium spp. was recorded in FD2 in both varieties, whereas it had the highest percentage in the traditional regional rate (FD-R) (Table 5). The presence of Fusarium on the external surface tissue demonstrates that this was a soilborne species where cormels were produced. However, such cormels did not show any symptoms of external rot as previously observed in other studies reported by González-Pérez et al. (2009) in the same area of study.

Table 4. Size $(\mathrm{mm})$ classification and cormel total fresh weight distribution of two gladiolus varieties in response to four fertilization rates (FD; $\mathrm{kg} \mathrm{ha}^{-1}$ ) (Tlacotepec de José Manzo, EI Verde, Puebla) during the 2009 spring-summer cycle.

\begin{tabular}{lccccl}
\hline & \multicolumn{5}{c}{ Size classification } \\
\cline { 2 - 6 } FD & $10-12$ & $8-10$ & $6-8$ & $4-6$ & $2-4$ \\
\hline FD1 & $5.7 \mathrm{~cd}$ & $45.0 \mathrm{ab}$ & $110.2 \mathrm{bc}$ & $11.0 \mathrm{ce}$ & $1.214 \mathrm{ce}$ \\
FD2 & $12.2 \mathrm{ab}$ & $23.0 \mathrm{de}$ & $116.9 \mathrm{ab}$ & $13.0 \mathrm{ab}$ & $1.215 \mathrm{~cd}$ \\
FD3 & $5.5 \mathrm{de}$ & $40.0 \mathrm{bc}$ & $27.5 \mathrm{~d}$ & $5.0 \mathrm{de}$ & $1.296 \mathrm{~b}$ \\
FD-R & $12.7 \mathrm{a}$ & $21.0 \mathrm{e}$ & $31.4 \mathrm{~cd}$ & $14.0 \mathrm{a}$ & $1.381 \mathrm{ab}$ \\
Mean & 9.0 & 32.3 & 71.5 & 10.0 & 1.27 \\
& & & 'Espuma' \\
FD1 & $6.3 \mathrm{bc}$ & $46.0 \mathrm{a}$ & $106.8 \mathrm{~cd}$ & $12.0 \mathrm{bc}$ & $1.212 \mathrm{cf}$ \\
FD2 & $2.0 \mathrm{ef}$ & $7.8 \mathrm{e}$ & $125.0 \mathrm{a}$ & $12.0 \mathrm{bc}$ & $1.146 \mathrm{~g}$ \\
FD3 & $5.3 \mathrm{ef}$ & $37.5 \mathrm{~cd}$ & $29.1 \mathrm{~d}$ & $12.0 \mathrm{a}$ & $1.206 \mathrm{def}$ \\
FD-R & $3.2 \mathrm{df}$ & $8.0 \mathrm{e}$ & $30.7 \mathrm{~d}$ & $3.7 \mathrm{~cd}$ & $1.832 \mathrm{a}$ \\
Mean & 4.2 & 24.7 & 72.9 & 9.9 & 1.34 \\
\hline
\end{tabular}

FD1: 65N-14.9P-171K-16.6Mg-31.2Ca-0.0B-0.0S; FD2: $40.5 \mathrm{~N}-24 \mathrm{P}$ $171 \mathrm{~K}-23 \mathrm{Mg}-37.2 \mathrm{Ca}-0.2 \mathrm{~B}-8.5 \mathrm{~S}$; FD3: $81 \mathrm{~N}-24 \mathrm{P}-171 \mathrm{~K}-23 \mathrm{Mg}-37.2 \mathrm{Ca}$ $0.2 \mathrm{~B}-0.0 \mathrm{~S}$; FD-R (regional traditional fertilization rate): $81 \mathrm{~N}-24 \mathrm{P}-171 \mathrm{~K}$ $23 \mathrm{Mg}-37.2 \mathrm{Ca}-0.0 \mathrm{~B}-0.0 \mathrm{~S}$.

Same letter within a column indicates no significant differences according to the Kruskal-Wallis rank mean test $(\mathrm{p} \leq 0.05)$.

Table 5. Percentage of fungal isolates in cormels of two gladiolus varieties in response to four fertilization rates (FD; kg ha ${ }^{-1}$ ) (Tlacotepec de José Manzo, El Verde, Puebla) during the 2009 spring-summer cycle.

\begin{tabular}{lcc}
\hline & External tissue & Internal tissue \\
\cline { 2 - 2 } FD & Fusarium spp. & F. oxysporum \\
\hline FD1 & 'Borrega Roja' & \\
FD2 & $63.7 \mathrm{ab}$ & $3.7 \mathrm{c}$ \\
FD3 & $15.0 \mathrm{e}$ & $0.0 \mathrm{c}$ \\
FD-R & $40.0 \mathrm{~cd}$ & $3.7 \mathrm{c}$ \\
& $70.0 \mathrm{ab}$ & $40.0 \mathrm{a}$ \\
FD1 & 'Espuma' & \\
FD2 & $51.3 \mathrm{bc}$ & $0.0 \mathrm{c}$ \\
FD3 & $20.0 \mathrm{de}$ & $0.0 \mathrm{c}$ \\
FD-R & $42.5 \mathrm{c}$ & $3.7 \mathrm{c}$ \\
\hline
\end{tabular}

FD1: 65N-14.9P-171K-16.6Mg-31.2Ca-0.0B- 0.0S; FD2: 40.5N-24P$171 \mathrm{~K}-23 \mathrm{Mg}-37.2 \mathrm{Ca}-0.2 \mathrm{~B}-8.5 \mathrm{~S}$; FD3: $81 \mathrm{~N}-24 \mathrm{P}-171 \mathrm{~K}-23 \mathrm{Mg}-37.2 \mathrm{Ca}$ $0.2 \mathrm{~B}-0.0 \mathrm{~S}$; FD-R (regional traditional fertilization rate): $81 \mathrm{~N}-24 \mathrm{P}-171 \mathrm{~K}-$ 23Mg-37.2Ca-0.0B-0.0S.

Same letter within a column indicates no significant differences according to the Kruskal-Wallis rank mean test $(\mathrm{p} \leq 0.05)$.
Internal tissue. In both varieties no significant differences were shown with FDs 1 to 3 although in 'Espuma', FD2 had $0.0 \%$ incidence of $F$. oxysporum (Booth, 1971; González-Pérez et al., 2009); this was followed by FD1 in the same variety (Table 5). In contrast, FD-R showed the highest percentage of $F$. oxysporum isolates.

From the physiological or nutritional point of view, FD2 followed by FD1 helped the MC to produce the best NcMC, TFW, and healthiest cormels. The strength of FD2 possibly relies on its lower $\mathrm{N}$ rate and adding $\mathrm{B}$ and $\mathrm{S}$ in relation to FD-R, which produced the worst cormels. However, assumptions can only be made since these three nutrients were not analyzed in separate experiments. They were selected for their in vitro negative effect on $F$. oxysporum colony development (González-Pérez, 2006). As mentioned before, $\mathrm{B}$ and $\mathrm{Ca}$ in carnation are good for Fusarium control (Engelhard, 1989) and to keep soil pH at 6.5-7.5. The beneficial effect of B was possibly also associated with strengthening the cormel cell wall since B participates in the maintenance and synthesis of cell walls and plasma membrane integrity (Cakmak and Romheld, 1997; Cara et al., 2002); this possibly helps to prevent infection by Fusarium.

As for adding $\mathrm{S}$, this nutrient should also contribute to less cormel rot at the base than in general; applying $\mathrm{S}$ directly to the soil has a beneficial effect on plants and helps them to reduce the development of fungi and other pathogens (Melgar et al., 2001); specifically, it reduces the amount of corm rot in gladiolus (Chandel and Deepika, 2010).

Regarding N, FD1 and FD2 had 20\% and 50\% less than FD-R, respectively. This nutrient is possibly a key element. There are indications that low $\mathrm{N}$ rates $\left(50 \mathrm{~kg} \mathrm{ha}^{-1}\right)$, such as in FD2, induce higher corm and cormel weight (Butt, 2005; Pant, 2005) and in some crops can control Fusarium wilt (Engelhard, 1989); some reports agreed with these studies for cormel TFW and health results and a high $\mathrm{N}$ rate reduces the physical and health quality of corms (González-Pérez, 2006).

In the study region, soil pH was 5.8 (Table 1) and the source of $\mathrm{N}$ applied to soil was mainly as $\mathrm{NH}_{4}$; thus, both these related facts can perhaps explain that $F$. oxysporum was undeveloped in internal tissue with FD2. Damage by Fusarium species in corn and eggplant decreased according to Datnoff et al. (2007), who found that this was due to acid $\mathrm{pH}$ and $\mathrm{NH}_{4}$ in the soil. Furthermore, it is possible that the amount of $\mathrm{N}$ applied in FD2 was adequate for gladiolus physiology so that cormel carbohydrate content was moderate (Bennett, 1993). For this reason, these cormels could have proper cell size and cell wall cellulose content, which should then induce mechanical strength to the vegetative seeds; all these facts could defend them against Fusarium cormel rot and later plant wilt in the field (Datnoff et al., 2007). In FD-R, the amount of $\mathrm{N}$ applied was believed to be excessive, so the cell wall was possibly weak and the cormels produced 
were succulent and thus had the highest Fusarium rate colonization. These assumptions were made in studies by Bennett (1993) on onion bulbs and Datnoff et al. (2007) in the role of $\mathrm{N}$ in plant physiology.

For FD1, this FD lacked B and S and had 20\% more $\mathrm{N}$ and less $\mathrm{P}, \mathrm{Ca}$, and $\mathrm{Mg}$ than FD2. The reduction of the last three nutrients was possibly not substituted by the soil composition, which had very low to medium amounts of them (Table 1). Thus, it could be deduced that these three nutrient rates should be adequate for some physiological or nutritional requirements of some varieties, or that their deficiencies were substituted by rates of $20 \%$ more $\mathrm{N}$. This could explain that FD1 in 'Borrega Roja' was equal to FD2 for NcMC, better in TFW, and close to 6-8 cormel size (physical seed qualities); in 'Espuma', it was equal to FD2 for healthy seed quality (internal tissue). The latter finding is also possibly related to the fact that the $\mathrm{N}$ : $\mathrm{P}$ proportion in FD1 was close to $3 \mathrm{~N}(65): 1 \mathrm{P}(14.9)$ $\mathrm{kg} \mathrm{ha}^{-1}$, which are rates that allow physical and healthy corm production (Vidalie, 2001). In general, several authors recommend the use of low $\mathrm{N}$ rates $\left(50 \mathrm{~kg} \mathrm{ha}^{-1}\right)$ and $\mathrm{B}$ incorporation for disease management in different crops because if the $\mathrm{N}$ concentration is exceeded, then the presence of various Fusarium species is promoted (Engelhard, 1989; Daughtrey and Benson, 2005; González-Pérez et al., 2011).

\section{CONCLUSIONS}

The physical quality and health characteristics of cormel vegetative seed were enhanced mainly with FD2 and the traditional regional rate FD-R was at an extreme disadvantage. In FD-R, the excess of $\mathrm{N}$ and lack of $\mathrm{B}$ and $\mathrm{S}$ seems to negatively affect vegetative seed generation in this ornamental plant. Future studies should be focused on identifying their single effects as well as any possible interaction between them.

\section{ACKNOWLEDGEMENTS}

We wish to thank Hector Sanchez for providing plant material and advice on agronomic crop management, the Colegio de Postgraduados-Campus Montecillo for the facilities provided for the development of this study, and to the National Council for Science and Technology (CONACYT) for financial support.

\section{LITERATURE CITED}

Bai, J.G., P.L. Xu, C.S. Zong, and C.Y. Wang. 2009. Effects of exogenous calcium on some postharvest characteristics of cut gladiolus. Agricultural Sciences in China 8(3):293-303.

Bennett, W.F. (ed.) 1993. Nutrient deficiencies and toxicities in crop plants. 202 p. APS-Press, St. Paul, Minnesota, USA.

Bobadilla, S.E., y C. Chimenti. 2013. Efectos del boro sobre la producción y calidad de flor en tulipán cv. Rococó producidos en maceta. Horticultura Argentina 32(78):30-38.
Booth, C. 1971. The genus Fusarium. 237 p. Commonwealth Mycological Institute, Kew Surrey, UK.

Butt, S.J. 2005. Effect of N, P, K on some flower quality and corm yield characteristics of gladiolus. Journal of Tekirdag Agricultural Faculty 2:212-214.

Cakmak, I., and V. Romheld. 1997. Boron deficiency induced impairment of cellular functions in plants. Plant and Soil 193:7183.

Cantor, M., and J. Tolety. 2011. Gladiolus. p. 133-159. In C. Cole (ed.) Wild crop relatives: Genomic and breeding resources. Springer-Verlag, Berlin, Germany.

Cara, F.A., E. Sánchez, J.M. Riz, and L. Romero. 2002. Is phenol oxidation responsible for the short term effects of boron deficiency on plasma membrane permeability and function in squash root? Plant Physiology and Biochemistry 40:853-858.

Chandel, S., and R. Deepika. 2010. Recent advances in management and control of Fusarium yellows in Gladiolus species. Journal of Fruit and Ornamental Plant Research 18:361-380.

Cohat, J. 1993. Gladiolus. p. 297-320. In De Hertogh, A., and M. Le Nard (eds.) The physiology of flower bulbs: A comprehensive treatise on the physiology and utilization of ornamental flowering bulbous and tuberous plants. Elsevier, Amsterdam, The Netherlands.

Datnoff, L.E., W.H. Elmer, and D.M. Huber. 2007. Mineral nutrition and plant disease. 278 p. APS-Press, St. Paul, Minnesota, USA.

Daughtrey, M.L., and D.M. Benson. 2005. Principles of plant health management for ornamental plants. Annual Review of Phytopathology 43:141-169.

Elmer, W., and R.J. McGovern. 2004. Efficacy on integrating biological with fungicides for the suppression of Fusarium wilts of cyclamen. Crop Protection 23:909-914.

Engelhard, W.A. 1989. Soilborne plant pathogens: Management diseases with macro and microelements. 216 p. American Phytopathological Society Press, Jodhpur, India.

García, E. 2004. Modificaciones al sistema de clasificación climática de Köppen. Serie Libros $N^{\circ}$ 6. 156 p. Instituto de Geografía, Universidad Nacional Autónoma de México (UNAM), Ciudad de México, México.

González-Pérez, E. 2006. Calidad iónica del agua en relación a la nutrición del gladiolo y patógenos del cormo. Tesis de Maestría en Ciencias Agrícolas. Colegio de Postgraduados, Programa de Recursos Naturales, Montecillo-Texcoco, Estado de México, México.

González-Pérez, E., O.J. Ayala-Garay, J.A. Carrillo-Salazar, G. García de los Santos, M.J. Yáñez-Morales, and J. Juárez-Muñoz. 2011. A study of development, flower quality and fertilization in gladiolus (Gladiolus grandiflorus Hort.) Revista Fitotecnia Mexicana 34:277-283.

González-Pérez, E., M.J. Yáñez-Morales, H.M. Ortega-Escobar, and J. Velázquez-Mendoza. 2009. Comparative analysis among pathogenic fungal species that cause gladiolus (Gladiolus grandiflorus Hort.) corm rot in Mexico. Revista Mexicana de Fitopatología 27:45-52.

Gullino, M.L., J. Katan, and A. Garibaldi. 2012. Fusarium wilts of greenhouse vegetable and ornamental crops. APS-Press, St. Paul, Minnesota, USA.

Halder, N.K., R. Ahmed, S.M. Sharifuzzaman, B.K. Anzu-Man-Ara, and M.A. Siddiky. 2007. Effect of boron and zinc fertilization on corm and cormel production of gladiolus in grey terrace soils of Bangladesh. International Journal of Sustainable Crop Production 2:85-89.

Hossian, M.J., M.R. Amin, S. Choudhury, and J. Uddain. 2011. Effect of corm size and different doses of phosphorous on the growth, corm and cormel development of gladiolus. Libyan Agriculture Research Center Journal International 2:9-14.

Khan, M.A., and I. Ahmad. 2004. Growth and flowering of Gladiolus hortalanus L. cv. Wind song as influenced by various levels of NPK. International Journal of Agriculture \& Biology 6:10371039 . 
Kruskal, W.H., and W.A. Wallis. 1952. Use of ranks in one-criterion variance analysis. Journal of the American Statistical Association 47(260):583-621.

Larson, A.R. 1992. Introduction to floriculture. Academic Press, San Diego, California, USA.

Lehry, S.M., A.A. Kurd, M.A. Rind, and N.A. Bangulzai. 2011. The response of Gladiolus tristis L. to $\mathrm{N}$ and $\mathrm{P}_{2} \mathrm{O}_{5}$ fertilizers. Sarhad Journal Agricultural 27:185-188.

Leslie, J.F., and B.A. Summerell. 2006. The Fusarium laboratory manual. Blackwell Publishing, Oxford, UK.

Martínez, G.A., y D.M.A. Martínez. 1998. Diseño de experimentos con fertilizantes. Publicación Especial $N^{\circ}$ 5. Sociedad Mexicana de la Ciencia del Suelo, Colegio de Postgraduados, Estado de México, México.

Melgar, M.R., E. Camozzi, D.M. Torres, y J. Lavandera. 2001. Fertilización potásica y clorada: Una herramienta eficaz para reducir la incidencia de enfermedades. Revista Fertilizar 23:1620.

Nelson, E.P., T.A. Toussoun, and W.F.O. Marasas. 1983. Fusarium species. An illustrated manual for identification. The Pennsylvania State University Press, University Park, Pennsylvania, USA.
Pant, S.S. 2005. Effect of different doses of nitrogen and phosphorus on the corm and cormel development of gladiolus (Gladiolus sp.) cv. American beauty. Journal Institute of Agriculture Animal Sciences 26:153-157.

SAS Institute. 2009. SAS/SAT User's guide. Version 9. SAS Institute, Cary, North Carolina, USA.

Shaukat, S.A., S.Z. Ali Shah, Y. Ishaq, M. Ahmed, S.K. Shaukat, and S.W. Shoukat. 2012. Influence of phosphorus fertilization on gladiolus corm and flower production. Scientific Journal of Agricultural 1(5):105-111.

SIAP. 2012. Anuario del Servicio de Información Agroalimentaria y Pesquera, ciclos 2010. Secretaría de Agricultura, Ganadería, Desarrollo Rural, Pesca y Alimentación (SAGARPA), México D.F.

Vidalie, H. 2001. Producción de flores y plantas ornamentales. $3^{\mathrm{a}}$ ed Mundi-Prensa, Madrid, España.

Zubair, M. 2011. Effect of potassium fertility levels on gladiolus yield quality of cut flowers and corm production. Egypt Academic Journal Biology Science 2:17-27. 